\title{
PEMBANGUNAN KEMANDIRIAN EKONOMI MASJID CHENG HOO SURABAYA PERSPEKTIF MANAJEMEN STRATEGIS
}

\author{
Dian Marjayanti \\ STID Al-Hadid, Surabaya \\ dianmarjayanti@gmail.com
}

\begin{abstract}
Abstrak: Masjid Cheng Hoo Surabaya memulai usaha ekonomi untuk mewujudkan kemandirian masjid berbasis ekonomi madani. Menariknya, wujud kemandirian tersebut, bukan hanya bertujuan untuk menambah kas masjid, namun juga memberdayakan masyarakat lewat usaha perternakan sapi salah satunya. Tujuan penelitian ini adalah mendeskripsikan strategi yang dilakukan Masjid Cheng Hoo Surabaya dalam mewujudkan kemandirian tersebut, mulai dari awal, beserta segala pertimbangan yang melingkupinya. Teori yang digunakan adalah perumusan strategi oleh Fred R. David. Metodologi yang digunakan adalah kualitatif dengan menggunakan wawancara semiterstruktur, observasi, dan dokumentasi. Hasil studi menunjukkan: (1) Misi kemandirian masjid yang dibangun selaras dan mendukung tercapainya visi masjid, (2) Strategi dihasilkan dari pemetaan kondisi internal meliputi : sumber daya pengurus, citra masjid, aset masjid, sistem kerja organisasi; sedangkan kondisi eksternal meliputi : kebutuhan jemaah sumber daya donatur dan pesantren, perkembangan usaha ritel serta kondisi ekonomi. (3) Strategi yang dimiliki berbasis pada kekuatan-peluang yaitu: (1) Merencanakan berbagai usaha ekonomi, meliputi : koperasi dan kafe, Cheng Hoomart, Cheng Hoo barkery dan peternakan sapi, (2) Membangun kerja sama dengan donatur, (3) Membangun kerja sama, (4) Membangun kesiapan SDM berupa pelatihan, dan (5) Penggunaan teknologi untuk pengawasaan. Strategi kelemahan-ancaman yakni membangun pola berfikir sumber daya manusia,serta Strategi kekuatan-kelemahan yakni membangun komitmen pengurus.

Kata kunci : kemandirian masjid, perumusan strategi, Masjid Cheng Hoo
\end{abstract}

Economic Independence of Cheng Hoo Mosque Surabaya: Strategic Management Perspective. Abstract: Cheng-Hoo Mosque - Surabaya has been developing economic efforts to realize civil economy-based mosque independence. Interestingly, the efforts do not only aim to increase mosque cash, but also to empower the community through, one of them, cattle farm. This study aims to describe the strategies carried out by this mosque in realizing this independence, starting from the beginning, along with all of the considerations. It uses strategy formulation by Fred R. David. It applies qualitative methodology by using semistructured interviews, observation and documentation. It indicates that: (1) the mosque's independence mission is harmoniously built and supports its vision; (2) the strategies from internal condition mapping, include: management resources, mosque image and assets, organizational work system, while from external conditions include: the congregation needs, resources of donors and pesantren, retail business development, and economic conditions; (3) its strategies are based on the strength of opportunities, namely: (1) Planning various economic enterprises, 
including cooperatives and cafes, Cheng Hoomart, Cheng Hoo Bakery and cattle farm, (2) Cooperating with donors, (3) building cooperations, (4) Improving human resources through trainings, and (5) Using technology for supervision. It also applies weakness-threat strategy to improve human resource mindset, and strengthweakness strategy to build management commitment.

Key words: mosque independence, strategic formulation, Cheng Hoo Mosque

\section{Pendahuluan}

Pada zaman Nabi Muhammad saw. Masjid memiliki beberapa fungsi yakni: sebagai tempat ibadah madhah (shalat wajib, sunah dsb), pusat pendidikan dan pengajaran Islam, sosialisasi informasi Islam, tempat penyelesaian perkara dan pertikaian, pusat kegiatan ekonomi, pusat kegiatan sosial dan politik (termasuk didalamnya untuk menyusun strategi peperangan). ${ }^{1}$ Hal ini menunjukkan bahwa fungsi masjid tidak sebatas tempat fisik untuk melakukan ibadah ritual saja, melainkan sebagai tempat yang mampu memberikan manfaat pemecahan masalah masyarakat di sektor.

Agar masjid mampu menjalankan fungsinya secara optimal, diperlukan berbagai persiapan bukan hanya program, tempat dan sumber daya manusianya saja yang disiapkan, melainkan juga sumber daya dana yang mampu memenuhi kebutuhan biaya program dan operasional masjid yang cukup besar, secara jangka panjang. Sementara itu, banyak masjid yang masih mengandalkan hasil kotak infak yang diadakan setiap jumat

1. Aziz Muslim, "Manajemen Pengelolaan Masjid", Aplikasia, Jurnal Aplikasi Ilmu-Ilmu Agama, Vol.V, No. 2, (Desember 2004), 107. http://digilib.uinsuka.ac.id/8309/1/AZIZ\%20MUSLIM\%20MANAJEMEN \%20PENGELOLAAN\%20MASJID.pdf.

2. Ibid., 110.

3. Moch. Cholid Wardi, “Pencarian Dana Masjid Di Jalan Raya Dalam Perspektif Hukum Islam", Al-Ihkam: Jurnal Hukum dan Pranata Sosial, Vol. 7 N o. 2, (Desember 2012), 334.

https://www.researchgate.net/profile/Moch Wardi/ publication/325556531 PENCARIAN DANA MASIID dan pengajian ${ }^{2}$, pencarian dana di pinggir jalan raya $^{3}$, secara jumlah tentutidak mencukupi.Ataupun karena dana yang diberikan donatur sangat bergantung dengan kondisi ekonomi mereka, sehingga sifatnya terbatas dan tidak menentu. Sehinggapihak masjid perlu memiliki sumber pendapatan lain diluar ZIS (Zakat Infak, dan Sedekah), yang mampu memberikan kepastian pemasukan secara jangka panjang. Salah satu sumber pendapatan masjid selain ZIS yakni berasal dari usaha masjid. Yang dimaksud usaha masjid ialah cara melakukan aktivitas ekonomi yang dapat menghasilkan uang untuk menunjang kas masjid, bisa berupa bidang jasa, perdagangan, dan bidang produksi. ${ }^{4}$

Masjid Cheng Hoo yang dikelola oleh Yayasan Haji Muhammad Cheng Hoo Indonesia (YHMCHI). ${ }^{5}$ Masjid tersebut memiliki beragam program layanan mulai dari ibadah, memperdalam pengetahuan Islam dengan adanya pembinaan mualaf ${ }^{6}$, pembinaan moral (kajian), kesehatan berupa klinik rumah sehat, pendidikan berupa

DI JALAN RAYA DALAM PERSPEKTIF HUKUM ISLA M/links/5b15e885aca272d43b7e8a6b/PENCARIANDANA-MASJID-DI-JALAN-RAYA-DALAM-PERSPEKTIFHUKUM-ISLAM.pdf.

4. Ariana Suryorini, "Pemberdayaan Masjid sebagai Fungsi Sosial dan Ekonomi bagi Jamaah Pemegang Saham Unit Usaha Bersama", Dimas: Jurnal Pemikiran Agama untuk Pemberdayaan, Vol.19 No. 2, (November 2019), 171.2, (November 2019), 171. https://core.ac.uk/download/pdf/287171587.pdf.

5. Wawancara dengan Hasan Basri, 7 November, 2016. 6. ibid. 
taman kanak-kanak dan play group yang bernama Istana Balita (IsBa), progam sosial berupa pengobatan gratis, toko/koperasi Cheng Hoomart, kantin Cheng Hoo hingga sarana rekreasi berupa lapangan olah raga basket dan tenis.

Dari gambaran progam tersebut, terlihat Masjid Cheng Hoo didirikan bukan hanya berfungsi sebagai tempat ibadah saja, melainkan mediasi atau wadah silaturahmi bagi berbagai etnis, tempat untuk mempelajari ajaran agama Islam, sebagai objek wisata yang menjadi ikon bagi kota Surabaya dan meningkatkan ekonomi untuk menunjung operasional masjid dan karyawannya. $^{7}$ Selain itu, juga memiliki fungsi area pertukaran budaya antara lokal dengan internasional melalui kunjungan yang dilakukan wisatawan mancanegara. ${ }^{8}$ Dan basis gerakan sosial, yang secara intensif dan masif turut mengentaskan masalah sosial yang dihadapi masyarakat, seperti pembagian makanan pokok gratis, santunan anak yatim piatu dan bantuan kesehatan. ${ }^{9}$

Hingga saat ini, untuk membiayai kebutuhan operasional masjid, sebagian besar bersumber dari donatur baik yang terdiri atas komunitas seperti alumni sekolah, pengusaha, atau pengunjung masjid. ${ }^{10}$ Karena sifat sumber pendanaan tersebut tidak menentu, mengingat sumber daya ekonomi tiap donatur terbatas. Sehingga muncul keinginan untuk untuk bisa mandiri secara ekonomi. Tidak terlalu menggantungkan pemasukan dari donatur. ${ }^{11}$

\footnotetext{
7. Wawancara dengan Hasan Basri, 7 November, 2016.

8. Achmad Muhibin Zuhri dan Winarto Eko Wahyudi,

"Teologi Sosial Muslim Tionghoa : Keimanan, Identitas Kultural Dan Problem Eksistensial", Empirisma, Jurnal pemikiran dan kebudayaan Islam, Vol. 29, No. 2, (Juli 2020), 107.1 doi: https://doi.org/10.30762/empirisma.v29i2.234.
}

Dilain pihak, adanya keinginan pengurus untuk merubah persepsi umat Islam dari masjid yang banyaknya meminta menjadi banyak memberi. ${ }^{12}$ Dalam artian melalui program tersebut diharapkan mampu memberikan pemasukan tambahan bagi masjid serta mampu memberikan manfaat bagi jemaah dan masyarakat sekitar masjid.

Atas pertimbangan tersebut, munculah gagasan membangun kemandirian ekonomi masjid yang mengusung konsep ekonomi madani . Yang dimaksud konsep tersebut adalah dalam melakukan usaha untuk memperoleh penghasilan, juga mampu memberikan kemanfaatan bagi orang disekitarnya. ${ }^{13}$ Disinilah letak kemenarikan kemandirian ekonomi masjid yang hendak dibangun masjid Cheng Hoo. Bukan hanya memikirkan penambahan kas masjid saja, melainkan juga mampu memberikan tambahan penghasilan bagi masyarakat/ orang lain. Salah satu wujud kemandirian Masjid Cheng Hoo Surabaya yakni mendirikan usaha pemberdayaan ekonomi. Salah satu wujudnya adalah mendirikan usaha penggemukan sapi yang melibatkan beberapa pesantren dan Cheng Hoomart. ${ }^{14}$

Lahirnya usaha tersebut, karena melihat adanya usaha bisnis pesantren yang berpeluang mampu menghasilkan pendapatan besar. Namun, karena pengelolaannya masih tradisional, sehingga jumlah produksinya dan pendapatan yang dihasilkannya belum optimal. Sementara pihak Masjid Cheng Hoo memiliki tekonologi

\footnotetext{
9. Ibid., 104.

10. Wawancara dengan Hasan Basri, 4 April, 2017.

11. Ibid.

12. Wawancara dengan Abd. Nawawi, 10 Mei, 2017.

13. Wawancara dengan Hasan Basri, 4 April, 2017.

14. Wawancara dengan Hasan Basri, 7 November, 2016.
} 
laser yang mampu meningkatkan produksi sapi secara berkualitas. ${ }^{15}$ Sehingga dengan kerja sama tersebut, bukan hanya memberikan pemasukan tambahan bagi Masjid Cheng Hoo, namun juga bagi pihak pesantren melalui sistem bagi hasil. ${ }^{16}$ Dan pada tahun 2018, usaha tersebut berkembang, YHMCHI melakukan kerja sama dengan warga RT 03/RW 03, Desa Cendono, Purwosari, Pasuruan. Yang harapan dari kerja sama tersebut mampu meningkatkan lapangan pekerjaan bagi masyarakat disana. ${ }^{17}$ Dengan membangun dan mengelola kekuatan ekonomi yang memanfaatkan segala potensi yang dimiliki oleh masjid, baik itu potensi jemaah, potensi lokasi masjid, potensi ekonomi masyarakat sekitar masjid, dan potensipotensi lainnya, tidak menutup kemungkinan problematika pengangguran dan kemiskinan, yang menjadi musuh utama umat Islam akan dapat diminimalisasi. ${ }^{18}$

Studi ini mengacu pada studi berjudul " Strategi Pengembangan Masjid ChengHoo Surabaya Berbasis Kemandirian Masjid". Adapun rumusan masalah yang diangkat dalam studi ini adalah "Bagaimana strategi yang dilakukan $\mathrm{YHMCHI}$ dalam membangun kemandirian masjid ChengHoo mulai dari pertama (awal membangun) dan pertimbangannya ?". Tujuannya, hendak mendeskripsikan strategi yang dilakukan oleh YHMCHI mulai dari awal hingga pelaksanaan pada tahun 2017 demi membangun kemandirian ekonomi masjid,

\footnotetext{
15. Wawancara dengan Soebiantoro, 7 April, 2017.

16 Hasil kerja sama tersebut, pihak pesantren memperoleh 5\%, wawancara dengan Pengurus pesantren Ngalah, 2017.

17. Tamam, "Ciptakan Kemandirian, YHMCHI Gandeng Peternak di Purwosari", ChengHoo.co, 13 Januari, 2021, http://chenghoo.co/2018/07/25/ciptakan-
}

beserta pertimbangannya. Manfaat penelitian ini, diharapkan mampu memperkaya khasanah penerapan perumusan strategi sehingga dapat memberikan inspirasi bagi lembaga dakwah khususnya masjid. Berkaitan dengan strategi apa saja yang diperlukan dalam membangun kemandirian ekonomi masjid mulai dari awal beserta pertimbangannya.

Pada kajian terdahulu, terdapat beberapa studi yang serupa dengan tema perumusan strategi dan kemandirian masjid yakni: (1) berjudul "Membangun Kekuatan Ekonomi Masjid (Studi Kasus Masjid Taqwa Muhammadiyah Padang)" yang memaparkan ragam kegiatan ekonomi masjid meliputi pangkas rambut, balai pengobatan, Bank Perkreditan Rakyat, bimbingan haji dan umrah, pengabdian masyarakat, Baitul Mal Tamwil, parkir kendaraan, toko buku, toko perlengkapansablon, taman pendidikan Alquran, WC umum, dan bidang penghimpunan infak. ${ }^{19}$ Namun, tidak ada pemaparan mengapa usaha tersebut yang dipilih beserta strategi yang dijalankan dalam mewujudkan kemandirian masjid; (2) Berjudul "Membangun Kekuatan Ekonomi Masjid (Studi Kasus Masjid Taqwa Muhammadiyah Padang)," yang juga membahas ragam bentuk usaha ekonomi Masjid Taqwa Muhammadiyah dalam membangun ekonomi umat seperti balai pengobatan, pangkas rambut, bimbingan haji dan umroh, Bank Perkreditan Rakyat,

kemandirian-yhmchi-gandeng-peternak-di-purwosari. (diakses 13 Januari 2021).

18. Dalmeri, "Revitalisasi Fungsi Masjid Sebagai

Pusat Ekonomi Dan Dakwah Multikultural", Walisongo, Vol. 22, No. 2 (November 2014), 338.

19. Siti Aisyah, "Membangun Kekuatan Ekonomi Masjid (Studi Kasus pada masjid Muhammadiyah Di Padang", Jurnal Syariah, Vol. II, No. II, Oktober 2013. 
kakus (WC) umum, dan sebagainya. ${ }^{20}$ Namun, dalam penelitian tersebut juga tidak membahas pertimbangan mengapa memilih usaha tersebut dan strategi yang ditempuh pihak masjid dalam membangun ekonomi masjid; (3) "Pemberdayaan Ekonomi Potensial Masjid Sebagai Model Pengentasan Kemiskinan", dengan menggunakan teori analisis SWOT, menghasilkan beberapa strategi yang perlu dilakukan masjid di Kota Banjarbaru beserta segala pertimbangan kondisi internal dan eksternal yang melingkupinya. ${ }^{21}$ Meskipun sama-sama menggunakan analisis SWOT, dalam memahami strategi membangun ekonomi masjid hanya mempertimbangkan dari kondisi internal dan eksternal, belum ada analisis keterkaitan/keselarasan antara strategi dengan visi. Dilain pihak, secara tujuan membangun ekonomi masjid disini memiliki orientasi yang berbeda yakni untuk mengentaskan kemiskinan.

Studi ini menggunakan teori perumusan Strategi menurut Fred R. David sebagai pisau analisanya. Karena teori tersebut, mampu memberikan kerangka berfikir memahami strategi secara komprehensif. Bukan hanya melihat dari kondisi internal dan eksternal saja, melainkan strategi tersebut harus selaras dengan visi dan misi yang dimiliki organisasi. Dilain pihak teori tersebut, banyakditerapkan dalam berbagai organisasi baik militer, bisnis, dan bahkan nirlaba, atau

20. Siti Aisyah, Membangun kekuatan Ekonomi Masjid (Studi Kasus Masjid Taqwa Muhammadiyah Padang), Jurnal Syari'a, Vol. II, No. II (Oktober 2013). doi: https://doi.org/10.32520/.v1i2.12.

21. Rozzana Erziaty, Pemberdayaan Ekonomi Potensial Masjid Sebagai Model Pengentasan Kemiskinan, AlIQTISHADIYAH jurnal ekonomi Syariah dan Hukum Ekonomi Syariah, Vol. II, No. II (Juni 2015). doi: http://dx.doi.org/10.31602/iqt.v2i2.377.

22. Muhammad Niltal Muna dan Meri Indri Hapsari, "Implementasi Manajemen Strategik Syariah Di BMT lembaga dakwah.Seperti dalam sebuah studi berjudul "Implementasi Manajemen Strategi Syariah Di BMT (Bayt al-Māl wa'l-Tamwīl) Amanah Ummah" diperoleh kesimpulan, bahwa BMT telah menerapkan manajemen strategi mulai dari tahap perumusan hingga implementasinya, yang mana prosesnya merupakan pengembangan dari konsep Fred R. David dan prinsip syariah. ${ }^{22}$ Hanya saja dalam teori tersebut, butuh penyesuaian terkait faktor internal dan eksternal konteks lembaga dakwah khususnya masjid. Serta penggunaan nilai-nilai Islam azas ketauhidan, orientasi duniawi-ukhrawi, dan motivasi mardhatillah (semata-mata karena Allah) disetiap tahapan manajemen strategi. ${ }^{23}$

Pendekatan penelitian deskriptif kualitatif karena rumusan masalah dan tujuan penelitiannya hendak memaparkan/ mengeksplorasi, ${ }^{24}$ strategi yang dilakukan oleh YHMCHI dalam membangun kemandirian masjid, beserta pertimbangan kondisi internal dan eksternal yang melingkupinya, secara alamiah/naturalistik (tanpa memberikan perlakuan apapun terhadap data). ${ }^{25}$ Metode yang digunakan wawancara semiterstruktur dengan menanyakan dasar berfikir dan gambaran kemandirian masjid Cheng Hoo, serta strategi yang dilakukan YHMCHi mulai dari awal. Pihak yang menjadi key informan yakni: Bapak Abd. Nurawi selaku Ketua

Amanah Ummah", JESTT, Vol. 2 No. 12, (Desember 2015). doi: http://dx.doi.org/10.20473/vol2iss201512pp10521068.

23. Shofyan Affandy, Dakwah Strategik Ancangan Teoritis \& Filosofis (Surabaya : Avvatera, oktober 2017), 141.

24. Sugiyono, Metode Penelitian Kuantitatif, Kualitatif dan R\&D (Bandung: Alfabeta,2012), 209.

25. Ibid., 8 
Umum YHMCHI, dan Bapak Subiantoro selaku bagian tim pengembangan ekonomi. Mereka berdua adalah pihak yang menggagas dan menjalankan strategi kemandirian ekonomi Masjid Cheng Hoo. Ustaz Hasan Basri selaku Ketua Pelaksana Harian YHMCHI yang dilibatkan dalam proses merumuskan kemandirian masjid. Ustaz Haryono Ong selaku Ketua Takmir yang sering berinteraksi dengan jama'ah dan donatur. Dan pihak pengurus pesantren yang dilibatkan dalam program kemandirian berupa pemberdayaan ekonomi yakni Ust. Ikhwan selaku pengurus pondok pesantren Ngalah. Serta data berupa observasi dan dokumentasi kegiatan terkait program kemandirian.

Proses analisis mengacu pada Miles dan Huberman, yaitu: (1) Tahap mereduksi data dari hasil wawancara, dokumentasi dan observasi dilapangan sesuai dengan rumusan masalah; (2) Data yang telah terkumpul diklasifikasikan berdasarkan temuan strategi dalam membangun kemandirian ekonomi Masjid Cheng Hoo. Dan variabel pemetaan internal dan eksternal yang mempengaruhi Masjid Cheng Hoo. Kemudian, dianalisis manakah yang menjadi kekuatan, kelemahan, peluang dan ancaman; (3) Selanjutnya akan dilakukan pembacaan dengan menghubungkan hasil analisis kondisi internal dan eksternal dengan tiap strategi. Diakhir, disimpulkan bahwa strategi tersebut lahir dari pencocokan SO, ST, WO dan WT. ${ }^{26}$ Untuk

26. Sugiyono, Metode Penelitian Kuantitatif, Kualitatif dan R\&D (Bandung:Alfabeta,2012), 246-253.

27. Miftahul Huda, Kemandirian Berbasis Wakaf di Masjid Besar Imam Ulomo Sampung Ponorogo, alihkam, Vol. 12 No.2 (D esembe $r$ 2017), 370-371. doi: 10.19105/alihkam.v12i12.1510.

28. Ahmad Rifai, Revitalisasi Fungsi Masjid Dalam Kehidupan Masyarakat Modern, Universum, Vol.10, memperoleh data yang valid, menggunakan teknik triangulasi sumber data dan metode.

\section{Kemandirian Ekonomi Masjid}

Kemandirian masjid adalah keadaan sebuah masjid mampu membiayai segala kebutuhan dalam menjalankan fungsinya dengan memanfaatkan segala sumber daya yang dimilikinya. ${ }^{27}$ Kebutuhan tersebut bisa melingkupi perluasan wilayah masjid, infrastruktur dan biaya operasional untuk menjalankan program masjid, seperti gaji karyawan masjid, biaya listrik, kebersihan, dan sebagainya

Makna Masjid bukan sebatas sebuah bangunan yang didirikan sebagai sarana mengabdi kepada Allah. ${ }^{28}$ Melainkan, sebuah lembaga atau organisasi yang didalamnya terdiri atas kumpulan beberapa orang/individu-individu yang memiliki kesamaan tujuan mendirikan masjid. Sehingga pendekatan untuk memahami kemandirian ekonomi, melalui bentuk kemandirian yang dimiliki seseorang/sekelompok orang.

Menurut Robert Havighurst dalam Suharman yang dikutip oleh Nuraida, ada beragam bentuk kemandirian yang melekat pada individu. Salah satunya yakni kemandirian ekonomi yakni mengatur ekonomi sendiri dan tidak tergantungnya kebutuhan ekonomi pada orang lain. ${ }^{29}$

No. 2 (Juli 2016), 162. doi: https://doi.org/10.30762/universum.v10i2.256.

29. Nuraida, "Konsep Kemandirian Dalam Pengembangan Masjid", Yonetim, Vol 1 No 1 (2018), 7. http://jurnal.radenfatah.ac.id/index.php/yonetim/arti cle/view/2957. 
Sehingga bisa dimaknai kemandirian ekonomi masjid adalah keadaan masjid (pengurusnya) mampu membiayai segala kebutuhan baik perluasan fisik masjid, infrastruktur, dan biaya operasional yang dibutuhkan dalam menjalankan fungsinya, dengan memanfaatkan segala sumber daya yang dimilikinya.

Adapun beberapa bentuk usaha dalam membangun kemandirian ekonomi masjid seperti: (1) Usaha guna menghimpun dan mengelola dana jemaah serta mengembangkan untuk kepentingan umat baik dalam bentuk koperasi ${ }^{30}$, BMT dan arisan jama'ah; (2) Penyewaaan ruang aula dan inventaris masjid (sound system, kursi, tenda, dan sebagainya)untuk berbagai kegiatan; (3) Membuka usaha milik masjid seperti membuka mini market atau koperasi masjid yang menjual berbagaikeperluan rumah tangga; ${ }^{31}$ (4) Memanfaatkan wakaf produktif masjid berupa tanah untuk mendirikan toko, swalayan, perkantoran, atau tempat pertemuan; 32

Pemberdayaan ekonomi, seperti persewaan tempat usaha, sehingga masyarakat dapat memanfaatkan tempat tersebut untuk berjualan. ${ }^{33}$

\section{Perumusan Strategi}

Manajemen strategik sebagai seni dan pengetahuan dalam merumuskan,

30. Dalmeri, "Revitalisasi Fungsi Masjid Sebagai. Pusat Ekonomi Dan Dakwah Multikultural", Walisongo, Vol. 22, No. 2 (November 2014), 336. doi: 10.21580/ws.22.2.269.

31. Miftahul Huda, "Kemandirian Berbasis Wakaf Di Masjid Besar ImamUlomo Sampung Ponorogo", AlIhkam, V O L . 12 No.2 (Desember 201 7), 370-371. doi: 10.19105/alihkam.v12i12.1510.

32. Nurodin Usman, "Varian Mauquf 'Alaih 'Am sebagai Alternatif dalamPengembangan Wakaf Produktif", alahkam, jurnal ilmu Syariah daN Hukum, Vol. 2, No. 1 mengimplementasikan, serta mengevaluasi keputusan-keputusan lintas-fungsional yang memampukan organisasi mencapai tujuannya. $^{34}$ Secara proses manajemen strategi terdiri atas 3 tahapan besar yakni perumusan strategi, menerapkan strategi, dan penilaian strategi. Fred R. David mendefinisikan strategi sebagai sebuah sarana dalam mencapai tujuan jangka panjang yang hendak dicapai. ${ }^{35}$ Dapat disimpulkan bahwa strategi adalah sebuah cara yang terencana untuk mencapai tujuan organisasi. Sementara perumusan strategi adalah proses dalam menetapkan cara untuk mencapai tujuan organisasi, dengan mempertimbangkan berbagai kondisi internal dan eksternal. Langkah dalam perumusan strategi meliputi:

Pertama, memahami visi dan misi organisasi. Visi ialah suatu keadaan masa depan organisasi yang mungkin dan dikehendaki, yang mencakup tujuan-tujuan spesifik. Sementara misi lebih terkait dengan perilaku masa kini. ${ }^{36}$ Bisa disimpulkan bahwa visi adalah kondisi bagaimana organisasi akan dibentuk dimasa depandan misi sendiri adalah tindakan yang dilakukan saat ini untuk mencapai visi yang akan dicapai. Sehingga makna memahami visi dan misi organisasi, adalah memahami gambaran apa yang hendak dicapai organisasi dan jalan yang akan dilalui untuk mencapainya. Jika dikontekskan, maka perlu memahami visi

(Januari-Juni 2017), $47 . \quad$ doi: https://doi.org/10.22515/al-ahkam.v2i1.757.

33. Muhammad Arif, Model Pemberdayaan Ekonomi Terhadap Kemandirian Masjid Haji Maraset, AtTawassuth, Vol.III, No.2 (2018), 430. doi: http://dx.doi.org/10.30821/ajei.v1i1.2744.

34. Fred R. David, Manajemen Strategis konsep (Jakarta: Salemba Empat,2012), 5.

35. Ibid.,18.

36. David, Manajemen Strategis, 88. 
berdirinya Masjid Cheng Hoo. Dan keterhubungan antara visi tersebut dengan misi kemandirian masjid Cheng Hoo.

Kedua, melakukan audit eksternal, yakni melakukan pendataan kondisi eksternal yang berpengaruh terhadap pencapaian tujuan organisasi. Tujuannya, memetakan faktor eksternal (diluar organisasi) berupa peluang yang dapat menguntungkan sebuah perusahaan dan ancaman yang harus dihindarinya. ${ }^{37}$ Keduanya bersumber dari situasi dan kondisi yang melingkupi kondisi mitra dakwah (mad'uw) sebagai objek/sasaran yang menerima produk. Dan situasi lingkungan makro yang berpengaruh pada pola pikir dan perilaku mitra dakwah keberadaan organisasi seperti situasi dan kondisi politik, ekonomi, sosial budaya, lingkungan, teknologi, dan konstelasi industri. Serta kesadaran baru dari sebagian. ${ }^{38}$

Jika dikontekskan dalam masjid yang yang dimaksud pasar disini adalah pihak pihak yang menjadi pengguna/konsumen dari usaha ekonomi masjid. Mereka bisa jama'ah ataupun wisatawan, mengingat Masjid Cheng Hoo memiliki fungsi sebagai obyek wisata. Adapula donatur selaku pihak yang dilibatkan dalam mendirikan usaha ekonomi masjid sebagai penyokong sumber daya baik dana dan infrastruktur. Dan pihak pesantren dan UKM (Usaha Kecil Mikro) yang diberdayakan serta dilibatkan dalam mengelola usaha ekonomi masjid dengan sistem kerja sama.

\footnotetext{
37. Ibid.,120.

38. Shofyan, Dakwah Strategik, 94-103.

39. Ibid., 178.

40. Ibid., 124-125.
}

Sementara kondisi dan situasi adalah kondisi yang melingkupi keberadaan Masjid Cheng Hoo terkait mendirikan usaha seperti kondisi sosial, ekonomi, politik, dsb. Dan kompetitor/pesaing yakni pihak yang memiliki usaha sejenis dengan usaha ekonomi yang digagas $\mathrm{YHMCHI}$.

Ketiga, melakukan audit internal, yakni melakukan pendataan kondisi internal yang berpengaruh terhadap pencapaian tujuan organisasi. Tujuannya untuk mengetahui kondisi internal yang menjadi kekuatan sehingga harus dioptimalkan dan kelemahan yang harus diperbaiki dalam mencapai visi dan misi organisasi. ${ }^{39}$ Jika dikontekskan dalam masjid sebagai organisasi nirlaba ialah sumber daya manusia yakni pengurus masjid baik aspek kemampuan, idealisme, struktur sosial (bisa berupa jabatan), sumber daya fisik meliputi aset masjid dan kesekretariatannya, sumber daya organisasi yakni visi,misi, tujuan, hingga sistem, dan prosedur yang dimilikinya. ${ }^{40}$

Keempat, menciptakan, mengevaluasi dan memilih strategi. Dalam proses menetapkan strategi, menggunakan SWOT (strenghtsweakness-opportunity-threats) sebagai metode analisisnya. Analisis SWOT adalah identifikasi berbagai faktor yang ada disekitar organisasisecara sistematis. ${ }^{41}$ Serta sebagai alat pencocokan yang penting, yang dapat membantu para manajer mengembangkan empat jenis strategi yakni: (1) strategi SO (kekuatan-peluang) adalah strategi dengan memanfaatkan segala kekuatan internal untuk memperoleh keuntungan sebanyak-banyaknya baik

41. Taufan Arifianto, "Analisis SWOT: Perumusan Strategi bidang Tabligh dan Kaderisasi Muhammadiyah pada Tanfidz Muktamar ke-46", Jurnal kajian \& pengembangan manajemen Dakwah, Vol. 06 no 02, (Desember 2016), 209. 
potensial maupun aktual dari konteks eksternal; (2) strategi WO (kelemahanpeluang) adalah strategi yang bertujuan untuk memperbaiki kelemahan internal dengan cara mengambil peluang dari eksternal; (3) Strategi ST (kekuatanancaman) adalah strategi dengan memanfaatkan kekuatan internal organisasi untuk mengatasi ancaman dari eksternal baik yang sifatnya aktual ataupun potensial; (4) Strategi WT (kelemahanancaman)adalah strategi bertahan dengan mengurangi kelemahan internal serta menghindari ancaman dari eksternal. ${ }^{42}$

\section{Profil Masjid Cheng Hoo Surabaya}

Masjid ini berdiri pada pada tanggal 15 Oktober 2001 atas gagasan dari HMY. Bambang Sujanto dan teman-teman PITI. Dan baru disahkan selesai pada tanggal 13 Oktober 2002 dan diresmikan pada $28 \mathrm{Mei}$ 2003 oleh Menteri Agama Republik Indonesia oleh Prof. Dr. Said Agil Husin AlMunawar, MA. ${ }^{43}$ Letak keunikan masjid tersebut selain pada bentuknya yang berupa kelenteng, tapi juga tidak memiliki pintu masjid, sebagaimana masjid yang sering ditemui pada umumnya. Hal ini menunjukkan bahwa Masjid Cheng Hoo terbuka bagi siapa saja, dari ras manapun, agama manapun, dan tidak memihak pada aliran manapun. ${ }^{44}$

42. David, Manajemen Strategis, 327.

43. Tasha Victoria Tanaja dan Lintu Tulistyantoro, "Kajian Ikonografi Ornamen pada Interior.

Masjid Cheng Hoo Surabaya", JURNAL INTRA, Vol. 5, No. 2, (2017), 174. http://publication.petra.ac.id/index.php/desaininterior/article/view/5763.
Memahami Visi Masjid dan Misi Kemandirian Ekonomi Masjid Cheng Hoo Surabaya

Latar belakang berdirinya Masjid Cheng Hoo, adanya kebutuhan untuk memberikan pembinaan yang efektif dan efisien bagi warga keturunan Tionghoa yang menjadi mualaf. Dilain pihak, muncul kesadaran pentingnya sarana pembauran untuk berinteraksi dalam kehidupan berbangsa dan bernegara, antara muslim Tionghoa dengan muslim pribumi. Sehingga Masjid Cheng Hoo tidak dipandang sebagai masjid yang ekslusif hanya untuk muslim Tionghoa. ${ }^{45}$ Dengan pembangunan masjid tersebut, diharapkan memiliki fungsi sebagai sarana dakwah dikalangan muslim keturunan Tionghoa dan pusat informasi Islam, saling bertukar pikiran sesama mereka maupun muslim lainnya. Itulah tujuan membangun sebuah masjid yang representatif, unik, dan menarik minat serta terbuka untuk umum, tidak eksklusif dan bisa menjadi tempat pembauran yang harmonis sesama muslim. ${ }^{46}$

Hal tersebut selaras dengan hasil wawancara dengan Ketua Umum dan Ketua Pelaksana Harian YHMCHI, terkait visi pendirian Masjid Cheng Hoo salah satunya ialah: (1) Meningkatkan kualitas ketakwaan kepada Allah. Khususnya bagi mualaf etnis Tionghoa yang mengalami diskriminasi; (2) Menjadi wadah yang memediasi perbedaan pemikiran antara suku Tionghoa dan pribumi

\footnotetext{
44. Wawancara dengan Ust. Hasan Basri, 7 November, 2016.

45. Wawancara dengan Hasan Basri, 7 November, 2016. Burnadi Hasan, Indahnya Perbedaan, Cetakan Kedua (Persatuan Islam Tionghoa Indonesia \& Yayasan Haji Muhammad Cheng Hoo : Surabaya, Oktober 2016), ix-x.

46. Ibid., xii.
} 
melalui dialog Kelslaman; ${ }^{47}$ (3) Mengingatkan masyarakat khususnya generasi muda muslim, untuk senantiasa meneladani Laksamana Cheng Hoo, dalam melakukan syiar dan berbuat baik kepada sesama tanpa memperhatikan ras, kaya miskin, dan golongan tertentu. ${ }^{48}$

Membangun kemandirian masjid merupakan salah satu misi dalam mewujudkan visi Masjid Cheng Hoo. Ide kemandirian tersebut diprakarsai oleh Bapak Abd. Nurawi dan Bapak Subiantoro. Ada beberapa pertimbangan yang mendasari gagasan tersebut yakni: (1) Munculnya kesadaran dari para pengurus, agar tidak terlalu bergantung pada sumbangan donatur yang cenderung tidak pasti dalam membiayai operasional Masjid; (2) Keinginan dari para pendiri sebagai generasi muda untuk giat bekerja, kreatif dan inovatif dalam mengembangkan masjid melebihi prestasi para pendiri terdahulu; ${ }^{49}$ (3) Membangun citra positif bahwa Islam merupakan agama yang memberikan rahmat bagi umat manusia, bukan agama yang mengajarkan umatnya untuk meminta-minta dan senantiasa menerima pemberian saja. ${ }^{50}$ Konsep kemandirian yang hendak dibangun berupa pemberdayaan ekonomi yang mengusung konsep ekonomi madani. Yang dimaksud konsep tersebut adalah dalam melakukan usaha untuk memperoleh penghasilan, juga mampu memberikan kemanfaatan bagi orang disekitarnya.

Dari gambaran konsep kemandirian masjid dan latar belakang lahirnya gagasan tersebut, nampak memiliki keselarasan dengan visinya yakni, pertama,

\footnotetext{
47. Ibid.

48. Wawancara dengan H. Abd. Nurawi, 10 Mei, 2017.

49. Ibid.
}

meningkatkan ketakwaan sebagai umat muslim, yang diwujudkan bukan hanya menjalankan ibadah ritual saja, melainkan memberikan kemanfaatan bagi orang lain. Melalui kemandirian masjid yang dijalankan berdasarkan prinsip ekonomi madani, usaha yang direncanakan tidak hanya memberikan penghasilan tambahan bagi masjid, melainkan juga pihak lain yang dilibatkan (misalkan pondok pesantren).

Kedua, sebagai tempat memediasi menyatukan antara golongan atau etnis yang berbeda sehingga terjalin ukhuwah. Salah satu upaya membangun ukhwah tersebut selain melalui pertukaran pemikiran, juga dalam bentuk perniagaan. Sebagaimana yang dilakukan Rasulullah saat hijrah pertama kali dari Mekah ke Madinah. Beliau mendirikan Masjid Quba serta menyatukan suku Aus dengan Khajraj, salah satunya dalam bentuk perdagangan. Terlihat dari usaha ekonomi masjid salah satunya peternakan sapi yang melibatkan pengurus, donatur yang mayoritas adalah pengusaha baik dari etnis Tionghoa/bukan, yang beragama muslim/bukan, dan dengan pihak pesantren. ${ }^{51}$ Meskipun mereka berbeda etnis, agama dan bahkan pola berfikir, namun mereka mampu dipertemukan dan disinergiskan dalam bentuk kerja sama yang saling menguntungkan.

Ketiga, adanya usaha ekonomi masjid, diharapkan juga mampu menjadi inspirasi generasi muda, terutama para pengurus Masjid Cheng Hoo yang masih muda. Untuk senantiasa menghasilkan program yang mampu memberikan kemanfaatanbagi masyarakat disekitarnya. Seperti adanya

\footnotetext{
50. Wawancara dengan Soebiantoro, 7 April, 2017.

51. Ibid.
} 
usaha peternakan sapi tersebut, bukan hanya memberikan penghasilan tambahan bagi pihak pesantren dan keluarga santri, namun juga ketrampilan. $\mathrm{Hal}$ ini sebagaimana yang telah dicontohkan oleh Laksamana Cheng Hoo, bukan hanya fokus pada menyiarkan ajaran Islam tapi juga berbuat baik kepada orang lain tanpa memandang ras, kaya, atau miskin.

Demi mewujudkan visi masjid tersebut, tentu saja masjid Cheng Hoo memiliki beberapa program bukan hanya untuk menjalankan fungsi sebagai tempat ibadah saja, melainkan sarana membangun kerukunan umat dan turut memecahkan masalah sosial. Untuk menjalankannya tentu membutuhkan dana yang cukup besar. Dengan adanya misi kemandirian Masjid tersebut, akan memberikan pemasukan tambahan bagi kas masjid demi mendukung kesuksesan program tersebut.

\section{Kondisi Eksternal Masjid Cheng Hoo Surabaya.}

Langkah selanjutnya adalah melakukan analisis kondisi eksternal yang menjadi pijakan dalam menetapkan strategi/langkah dalam membangun kemandirian ekonomi masjid. Pertama, pasar, mereka adalah masyarakat yang menikmati layanan masjid baik sebagai obyek wisata maupun tempat ibadah. Dilihat dari rata-rata profil pengunjung masjid, yakni: (1) wisatawan baik mancanegara dan lokal yang tertarik untuk melihat arsitekur masjid Cheng Hoo. Tak jarang mereka juga membawa pernakpernik Masjid Cheng Hoo sebagai souvenir; ${ }^{52}$ (2) Remaja yang banyak menggunakan

52. Wawancara dengan Soebiantoro , 7 April, 2017. fasilitas lapangan olah raga, khususnya lapangan basket. Kondisi ini sangat jauh berbeda ketika pihak masjid membuka persewaan lapangan tenis yang cenderung sepi; (3) Keluarga, yang saat pengurus masjid menanyakan alasan berkunjung ke Masjid Cheng Hoo, rata-rata menyampaikan ingin menanamkan nilai-nilai Islam semenjak dini kepada anak-anak mereka. ${ }^{53}$

Banyaknya wisatawan, remaja dan keluarga berkunjung ke Masjid Cheng Hoo surabaya, tentu tak terlepas dari letak masjid yang cukup strategis, berada di surabaya pusat, yang dikelilingi oleh perumahan, perkantoran, dan sekolah kompleks sehingga mudah diakses. Di samping Masjid Cheng Hoo Surabaya merupakan salah satu obyek wisata religi Surabaya yang senantiasa di promosikan oleh pihak Pemerintah Daerah, sehingga membuatnya semakin banyak dikenal.

Untuk memahami kebutuhan pasarnya, pihak pengurus YHMCHI baik ketua pelaksana harian dan takmir senantiasa bertanya kepada para pengunjung dan jemaah apa yang menjadi harapan mereka, apakah mereka sudah puas dengan program dan layanan yang ada dalam masjid Cheng Hoo. Hal ini dilakukan untuk meningkatkan kualitas program masjid. Serta memantau jumlah pengguna layanan yang ada untuk melihat apakah memang layanan tersebut cukup diminati atau tidak, salah satunya berkaitan dengan persewaan lapangan olah raga.

Kondisi kebutuhan dan keinginan pasar tersebut, tentu menjadi peluang bagi pengurus Masjid Cheng Hoo untuk

53. Wawancara dengan Ust. Hasan Basri, 7 November, 2016. 
mendirikan usaha ekonomi yang mampu menawarkan produk berupa barang/jasa sesuai kebutuhan dan keinginan mereka.

Kedua, donatur disini adalah pihak yang diajak kerja sama dalam mewujudkan kemandirian Masjid Cheng Hoo. Mayoritas mereka adalah pengusaha sukses dan berpengalaman dibidangnya. Mereka merupakan orang yang memiliki tingkat kesibukan tinggi sehingga menganggap waktu adalah hal yang berharga. ${ }^{54}$ Secara karakteristik membangun kerja sama dengan orang lain memperhitungkan aspek keuntungan dan kepercayaan. ${ }^{55}$ Tingkat kepedulian sosialmereka beragam. Ada yang berasal dari etnis Tionghoa dan ada pula yang tidak, meskipun mayoritas berasal dari Tionghoa. Secara agama ada yang muslim adapula yang non muslim. ${ }^{56}$ Kecenderungan mereka adalah orang yang mengenal Masjid Cheng Hoo dan mengenal Bpk. Abd. Nurawi selaku Ketua YHMCHI dan pengusaha yang juga berasal dari etnis Tionghoa. ${ }^{57}$

Kondisi donatur yang mayoritas adalah pengusaha sukses, ini menunjukkan adanya potensi kemampuan, pengalaman, dan modal dana yang berpeluang untuk bisa dilibatkan menjadi investor dalam menjalankan usaha ekonomi masjid. Peluang ini sifatnya semakin besar, apalagi banyak diantara mereka yang sudah mengenal Bpk. Abd. Nurawi, yang memiliki kesamaan latar belakang sebagai seorang pengusaha sukses dan berasal dari etnis Tionghoa serta selaku Ketua YHMCHI. Sehingga semakin memudahkan untuk mengajak mereka terlibat. Secara karakteristik donatur yakni: (1) Disiplin, (2) Rasional dalam mengambil keputusan, mempertimbangkan aspek

\footnotetext{
54. Wawancara dengan Hasan Basri, 4 April, 2017.

55. Wawancara dengan H. Abd. Nurawi, 10 Mei, 2017.

56. Ibid.
}

untung dan rugi, cenderung membuat mereka selektif dan tidak mudah dalam menerima sebuah tawaran program.

Ketiga, kondisi pesantren yang dilibatkan sebagai objek yang diberdayakan ekonominya yakni pesantren Ngalah di Purwoasri, Pesantren Al-Amin dan Nurul Jadid di Probolinggo. Ketiga pesantren tersebut memiliki kesamaan karakter yakni : (1) Memiliki jumlah santri yang sangat banyak diatas 10.000 santri; (2) Kyai yang mengajar kebanyakan berasal dari lulusan Al-Ahzar; (3) Untuk membiayai aktivitasnya, beberapa pondok memiliki usaha sendiri seperti pesantren Ngalah memiliki usaha dagang grosir atau eceran garmen, bengkel, katering, pertenakan, dan perikanan; (4) Memiliki pandangan hidup harus zuhud yakni pasrah kepada Allah akan kondisi yang mereka hadapi saat ini. ${ }^{58}$

Adapun kondisi pesantren yang dipandang sebagai peluang adalah: (1) jumlah SDM yang banyak, tentu ini menjadi peluang mempertimbangkan kerealistisan menjalankan usaha dan memungkinkan pula memunculkan ide pengembangan usaha lain yang membutuhkan banyak SDM; (2) Beberapa diantara pesantren tersebut sudah memiliki usaha sendiri, meskipun masih menggunakan teknologi yang sederhana (konvensional), implikasinya secara hasil belum optimal, sehingga menjadi peluang tinggal dikembangkan yang sudah ada; (3) pengurus memiliki background pendidikan yang sama yakni lulusan universitas AlAhzar, Cairo. Hal ini menjadi peluang karena dengan relasi tersebut memudahkan dalam melakukan penawaran kerja sama. Di lain

\footnotetext{
57. Wawancara dengan Ust. Hariono Ong, 15 Mei, 2017.

58. Wawancara dengan Soebiantoro, 7 April, 2017.
} 
pihak, juga menjadi peluang mempercepat dalam mensinergiskan usaha dari ketiga pesantren tersebut menjadi sebuah perusahaan besar dibawah pengelolaan Masjid Cheng Hoo; (4) Pola pendidikan pesantren yang kental dengan tanaman nilai-nilai agama Islam, sehingga melahirkan sumber daya manusia yang baik secara moralitas yakni moral kejujuran dan tanggung jawab. ${ }^{59} \mathrm{Di}$ sisi lain juga terdapat hambatan dari budaya santai dan berserah diri kepada Allah (pasrah pada keadaan yang ada). ${ }^{60}$ Adanya budaya tersebut nampak dalam proses mereka dalam menjalankan usaha ekonomi pesantren yang cenderung berjalan apa adanya dan tidak ada inovasi salah satunya terkait teknologi untuk meningkatkan produksi. Tentu saja hal membuat mereka cenderung sulit untuk diajak mengembangkan usaha.

Keempat, terdapat Usaha Kecil Menengah (UKM) sebanyak 300 UKM yang telah mengikuti program pemberdayaan Masjid Cheng Hoo baik yang sudah punya usaha maupun yang merintis usaha, termasuk para jemaah. ${ }^{61}$ Mereka memiliki sumber daya manusia dan komitmen untuk menjadi mandiri. Kondisi ini menjadi peluang mengajak kerja sama mendirikan usaha yang mampu memberdayakan mereka dan menambah pemasukan masjid. Namun, mereka masih memiliki pemikiran dalam melakukan usaha hanya memikirkan duniawi saja (keuntungan materi). ${ }^{62} \mathrm{Hal}$ ini tentu saja menjadi hambatan lantaran berbeda dengan prinsip ekonomi madani yang dimiliki Masjid Cheng Hoo.

59. Wawancara dengan Soebiantoro, 7 April, 2017.

60. Ibid.

61. Wawancara dengan Abd. Nurawi, 10 Mei, 2017.
Kelima, lingkungan makro yang disoroti oleh pengurus Masjid Cheng Hoo adalah minimnya produksi daging sapi di Indonesia, implikasinya harus mengimpor dari negara lain. Sementara daging sapi sangat dibutuhkan untuk pemenuhan gizi masyarakat Indonesia. ${ }^{63}$

Keenam, pesaingpengurus Masjid Cheng Hoo tidak terlalu banyak memaparkan pertimbangan dari aspek kompetitor. Mereka menyoroti usaha waralaba seperti indomaret dan alfamart yang telah memiliki banyak cabang. Sehingga mereka dipercaya pihak produsen besar seperti unilever sebagai distributornya. Dari merekalah pengurus Masjid Cheng Hoo terinspirasi membentuk usaha dengan sistem holding company. Yakni sebuah perusahaan besar yang terdiri atas berbagai usaha ekonomi pesantren, yang nantinya dibantu oleh Masjid Cheng Hoo dalam mensinergiskan pengelolaannya ${ }^{64}$

Jika disimpulkan beberapa kondisi eksternal yang menjadi peluang dan ancaman yakni, aspek peluang: (1) Tingginya minat wisatawan lokal dan mancanegara berkunjung ke Masjid Cheng Hoo(O1); (2) Kebutuhan dan keinginan pihak keluarga untuk memperkaya wawasan keislaman terkait pribadi, usaha, keluarga, dan kebutuhan membangun spiritualitas anak (O2); (3) Trend remaja terhadap olah raga basket (03); (4) Donatur yang memiliki sumber daya kemampuan, dana, infrastrukur, teknologi, dan relasi (04); (5) Pesantren yang memiliki sumber daya manusia, memiliki kesamaan relasi dan usaha mandiri yang bisa dioptimalkan(05);

\footnotetext{
62. Wawancara dengan H. Abd. Nurawi, 10 Mei, 2017.

63. Ibid.

64. Ibid.
} 
(6) 300 UKM dan jemaah masjid (06); (7)Terbatasnya pasokan daging sapi di Indonesia (07), perkembangan usaha ritel menjadi inspirasi bagi $\mathrm{YHMCHI}$ untuk mendirikan usaha Cheng Hoomart (08); dan Ancaman: (1) Pandangan budaya santai dan menyerahkan semua kepada Allah dimiliki pesantren (T1) dan kondisi UKM yang memiliki pandangan berbeda dengan konsep ekonomi madani (T2).

\section{Kondisi Internal Masjid Cheng Hoo}

Berikut ini merupakan beberapa kondisi internal yang menjadi pertimbangan lahirnya strategi dalam membangun kemandirian masjid, yaitu, pengurus YHMCHI dapat diklasifikasikan menjadi dua yakni pengurus yang profesional seperti Bpk. Hasan Basri selaku ketua pelaksana harian, dan pengurus yang merangkap sebagai pengusaha, seperti Bpk. Abd. Nurawi selaku Ketua yayasan $\mathrm{YHMCHI} .{ }^{65}$ Sebagai pengurus profesional, mereka lebih mudah ditemui di kantor yayasan bilamana hendak mengadakan rapat menyusun strategi kemandirian dan menjalankannya, kondisi ini bisa dikatakan sebagai kekuatan. Sementara itu, bagi pengurus yang merangkap karena banyak memiliki kesibukan diluar. Sehingga cukup sulit meluangkan waktu untuk mengikuti rapat menyusun strategi atau menjalankan program, bisa dikatakan sebagai kelemahan. Namun, adanya agenda rutin forum silaturahmi antara pengurus dengan sesepuh setiap satu minggu sekali pada hari jumat, bisa dimanfaatkan untuk mengatasi hambatan tersebut.
Pengurus yang bekerja di YHMCHI secara profesional memiliki tingkat pendidikan yang beragam mulai dari lulusan SMA hingga S2. Pihak YHMCHI menggaji mereka secara profesional. Karena itulah aturan penegakan kerja, dan prosedur menjalankan pekerjaan cukup ditekankan. Salah satunya adanya mesin absen pengurus masjid, dan penerapan SOP bagi pengurus masjid diberbagai lini. ${ }^{66}$ Kondisi SDM yang memiliki tingkat pendidikan min. SMA, dikatakan memiliki kemampuan berfikir pemecahan masalah yang baik. Dan dengan budaya senantiasa disiplin, menjalankan tugas sebagaimana SOP, hal ini menjadi kekuatan karena SDM siap secara kemampuan dan moralitas, dalam menjalankan program kemandirian masjid.

Sementara, pengurus yang merangkap sebagai pengusaha, banyak yang memiliki jaringan atau relasi dalam menjalankan usahanya. Disamping itu mereka juga memiliki pengalaman yang banyak dalam mengelola sebuah usaha hingga berkembang dan memperoleh banyak keuntungan. Salah satunya adalah Bpk. Abd. Nurawi, sebagai Ketua YHMCHI. Beliau adalah seorang pengusaha yang cukup disegani oleh pengusaha lain seperti PT. Kapal Api, Bogasari dan sebagainya. Beliau banyak berinteraksi dengan beberapa pengusaha lain, sehingga memiliki banyak relasi baik dari etnis Tionghoa atau bukan, yang beragama muslim atau non muslim. Selain itu, beliau juga memliki banyak pengalaman bagaimana mengelola usaha sehingga mampu menghasilkan keuntungan yang banyak. Menurut penuturan ketua pelaksana harian, modal dana untuk menjalankan progam kemandirian masjid

66. Wawancara dengan Hasan Basri, 7 November, 2016. 
berasal dari Bapak Nurawi dan tidak mengambil dari dana infak maupun zakat (disingkat ZIS). Selama ini dana ZIS digunakan membiayai operasional masjid seperti perbaikan gedung dan gaji karyawan, serta melaksanakan kegiatan sosial setiap 2 bulan sekali, seperti pengobatan gratis, program beasiswa, bantuan dhuafa dsb. ${ }^{67}$ Untuk membiayai operasional masjid ini tinggal mekanismenya ketika usaha tersebut menghasilkan keuntungan maka keuntungannya untuk masjid, sementara modalnya dikembalikan pada beliau. ${ }^{68}$

Kondisi pengurus yang memiliki banyak relasi dengan para pengusaha, tentu ini akan menjadi kekuatan bagi Masjid Cheng Hoo untuk mencari para donatur yang bersedia menjadi investor demi mendukung usaha kemandirian masjid, dengan memanfaatkan relasi tersebut. Dengan kemampuan dan pengalaman sebagai pengusaha, maka menjadi kekuatan dalam mencari peluang usaha kemandirian masjid, rencana menjalankan dan mengelola usaha tersebut agar senantiasa berkembang. Hal tersebut juga menjadi kekuatan untuk membangun kepercayaan para donatur (investor). Lantaran usaha tersebut dikelola oleh orang yang berpengalaman. Dan tidak menutup kemungkinkan pula, pengurus dengan kemampuan dan pengalaman tersebut ditunjuk sebagai pelatih SDM yang menjalankan usaha.

Nilai organisasi yang senantiasa menjunjung tinggi toleransi dan keterbukaan. Hal ini nampak dari visi masjid salah satunya sebagai tempat untuk memediasi perbedaan pemikiran antar golongan atau etnis melalui dialog, dari segi arsitektur yang memadukan

67. Wawancara dengan Hasan Basri, 4 April, 2017.

68. Wawancara dengan Hasan Basri, 4 April, 2017. antara budaya bangunan etnis Tionghoa dengan Islam, pengurus $\mathrm{YHMCHI}$ yang terdiri atas etnis Tionghoa dan Pribumi dan dalam berbagai kesempatan acara Milad $\mathrm{YHMCHI}$ juga turut mengundang donatur yang beragama Non Muslim. Hal ini tentu menjadi kekuatan internal bagi $\mathrm{YHMCHI}$ dalam membangun kerja sama dengan berbagai pihak saat mendirikan usaha ekonomi masjid, lantaran bersikap netral dan mampu mengakomodir berbagai perbedaan yang ada.

YHMCHI memiliki pola kontrol mingguan berupa forum silaturahmi yang diadakan setiap hari jumat. Hal ini menjadi kekuatan untuk membangun ikatan antar angggota organisasi melalui komunikasi yang intensif dan sarana menjaring ide-ide bagi pengembangan masjid, ditengah kesibukan para pengurusnya.

Infrastruktur disini lebih mengarah pada beberapa area masjid yang belum teroptimalkan seperti tempat parkir, area depan kafe, ruangan Masjid Cheng Hoo, dan ruangan dibelakang kafe. ${ }^{69}$ Sehingga area tersebut dapat dioptimalkan untuk usaha sebagai Cheng Hoo Bakery, sewa untuk pernikahan dan Cheng Hoo Mart. Tentu kondisi ini menjadi peluang usaha untuk memberikan pemasukan tambahan masjid.

Jika disimpulkan, ada beberapa kondisi internal yang menjadi kekuatan Masjid Cheng Hoo yakni: (1) Pengurus yang memiliki kemampuan dasar (pemecahan masalah yang baik), waktu dan moral untuk profesional (S1); (2) Pengurus yang juga menjadi pengusaha, memiliki kemampuan mengelola usaha dibidang masing-masing

69. Wawancara dengan Hasan Basri, 7 November, 2016. 
dan relasi (S2); (3) Figur dan relasi pengusaha Ketua YHMCHI (S3); (4) Milik Ketua YHMCHI sebagai modal usaha awal (S4); (5) Aset masjid yang bisa dikembangkan (S5); (6) Citra yang terbuka dan toleran terhadap perbedaan (56); (7) Pola kontrol mingguan berupa forum silaturahmi (S7). Dan kelemahan, tingkat kesibukan pengurus yang menjadi pengusaha cukup tinggi sehingga sulit ditemui (W1).

\section{Menetapkan Strategi Dalam Membangun Misi Kemandirian Masjid Cheng Hoo}

Berikut ini merupakan strategi/ langkah yang dilakukan oleh Masjid Cheng Hoo dalam membangun kemandirian ekonomi masjid:

\section{1) Membangun Komitmen Pengurus Masjid} Langkah awal yang dilakukan adalah, Ketua YHMCHI mengumpulkan beberapa pengurus untuk menyampaikan gagasan kemandirian masjid. Karena menurut beliau program ini butuh tim agar bisa berjalan. Dan sebuah tim harus ada kesamaan gerak sevisi dan misi. ${ }^{70}$ Pertemuan tersebut memanfaatkan waktu forum silaturahmi antar pengurus dan sesepuh yang diadakan seminggu sekali tiap hari jumat. Dalam pertemuan tersebut, beliau menekankan bahwa program kemandirian masjid, harus dijalankan secara ikhlas dan tidak mengharap imbalan, yang maksudnya lebih mementingkan kepentingan orang lain, dibandingkan kepentingan diri sendiri. ${ }^{71} \mathrm{Hal}$ ini selaras dengan prinsip ekonomimadani yang menjadi pondasi dalam menjalankan program kemandirian masjid. Yakni, melakukan usaha dengan memberikan kemanfaatan bagi sekitar.

\footnotetext{
70. Wawancara dengan Abd. Nurawi, 10 Mei, 2017.
}

Adapun beberapa pertimbangan yang mendasari strategi tersebut kekuatan pengurus yang merangkap sebagai pengusaha memiliki sumber daya kemampuan membangun usaha, dana, infrastruktur, dan relasi (S2) yang diharapkan mendukung dan keterlibatan dalam mewujudkan kemandirian masjid. Namun, mereka belum memiliki kesamaan pemikiran terkait ekonomi madani yang mendasari kegiatan ekonomi masjid. Sehingga perlu dibangun kesamaan pandangan tersebut. Hambatan terbesarnya (W1) adalah tingginya tingkat kesibukan para pengurus yang merangkap tersebut. Namun, dengan kondisi Ketua YHMCHI cukup disegani (S3) oleh para pengusaha termasuk pengurus Masjid Cheng Hoo, karena itulah ini menjadi kelebihan untuk bisa mengumpulkan para pengurus untuk terlibat mewujudkan gagasan kemandirian masjid. Serta dengan memanfaatkan pola kontrol minggu melalui forum jumat, yang telah menjadi kesepakatan dan rutin dilaksanakan, sehingga tidak menganggu kesibukan pengurus yang juga pengusaha (S7). Bila dicermati, strategi tersebut lahir tidak berpijak pada pembacaan kondisi eksternal. Melainkan lebih pada kekuatan dan kelemahan kondisi internal, karena arah strategi tersebut lebih pada penguatan internal organisasi. Yakni membangun pondasi awal dari sisi SDM berupa nilai dan tujuan akhir yang hendak dicapai dari kemandirian masjid.

\section{2) Mendirikan Usaha Demi Terwujudnya Kemandirian Ekonomi Masjid}

Tahap selanjutnya adalah menyusun program berupa usaha ekonomi masjid,

71. Ibid. 
yang dilakukan melalui forum silaturahmi jumatan. Disanalah terjadi proses diskusi sehingga melahirkan ide-ide baru yang saling melengkapi. Adapun beberapa usaha ekonomi Masjid Cheng Hoo sebagai berikut:

Pertama, Koperasi Cheng Hoo dan kafe di area masjid. Ide tersebut lahir dari peluang kondisi pasar banyak para wisatawan hadir baik dari dalam negeri dan luar negeri (01), keluarga (02), dan remaja yang mengunjungi masjid (O3), memungkinkan mereka membeli makanan dan minuman serta pernak pernik masjid. Peluang tersebut dapat dimanfaatkan, lantaran Masjid Cheng Hoo memiliki aset (area masjid) yang masih belum di optimalkan (S5).

Kedua, mendirikan Cheng Hoo Mart, di area masjid dan pesantren yang diajak bekerja sama. Saat ini usaha Cheng Hoomart sudah berjalan di beberapa pesantren, namun di area Masjid Cheng Hoo masih dalam proses. ${ }^{72}$ Usaha tersebut lahir melihat peluang pesantren yang memiliki sumber daya manusia, kesamaan relasi dan usaha mandiri yang bisa dioptimalkan (05). Dan peluang dari usaha ritel milik pesaing yang memberikan inspirasi untuk mendirikan usaha serupa (08). Sementara, donatur memiliki sumber daya kemampuan, dana, infrastruktur, dan relasi (O4), berpeluang untuk memberikan modal, atau pengetahuan bagaimana mendirikan usaha. Dari aspek internal pengurus yang memiliki kemampuan dasar (pemecahan masalah yang baik), waktu dan moral untuk profesional (S1). Serta Pengurus yang juga menjadi pengusaha, memiliki kemampuan mengelola usaha dibidang masing-masing dan relasi (S2) memungkinkan mampu mewujudkan usaha tersebut. Dengan kekuatan yang dimiliki (S1 dan S2) melahirkan strategi membuka Cheng Hoomart secara bertahap disalah satu pesantren, setelah sukses maka akan dikembangkan pada pesantren lainnya. Jangka panjangnya, usaha ketiga pesantren tersebut akan dikembangkan menjadi satu perusahaan besar sehingga memungkinkan memesan produk dalam jumlah besar dari produsen supaya memperoleh harga murah implikasinya harga jual ke pasar juga akan murah sehingga bisa bersaing dengan indomaret/alfamart.

Ketiga, Cheng Hoo Bakery. Program ini pengembangan dari usaha pemberdayaan masjid dengan UKM dan pihak PT. Bogasari. Usaha ini lahir dari peluang terdapat 300 UKM dan jemaah yang memiliki sumber daya manusia dan komitmen untuk menjadi mandiri (06), didukung dengan donatur memiliki sumber daya kemampuan, dana, infra, dan relasi, salah satunya adalah Bogasari yang bersedia membantu bahan, perangkat pembuatan kue dan bahkan pelatih untuk membuat kue (04). Serta kekuatan pengurus yang juga menjadi pengusaha, memiliki kemampuan mengelola usaha dibidang masing-masing dan relasi (S2) sehingga memungkinkan turut memberikan pelatihan usaha bagi UKM.

Keempat, usaha penggemukan sapi. Usaha tersebut lahir karena melihat peluang: (1) Pemenuhi kebutuhan daging sapi di Indonesia yang minim jumlahnya (07); (2) Adanya donatur, Prof. Tatang dan Prof. Heri yang memiliki teknologi laser layaknya fungsi USG yang dapat memantau kondisi

72. Wawancara dengan Abd. Nurawi, 10 Mei, 2017. 
perkembangan janinnya dapat membantu menghasilkan sapi berkualitas (O4). ${ }^{73}$ Dan keberadaan pondok pesantren memiliki beberapa peluang (05); (3) SDM yang banyak mulai dari pengurus, santri dan keluarga santri saja; (4) Nilai-nilai moral kejujuran yang telah menjadi kebiasaan disana menjadi nilai tambah tersendiri. Sehingga memungkinkan dilibatkan menjadi SDM dalam usaha tersebut dengan pendampingan dari pengurus yang juga menjadi pengusaha, memiliki kemampuan mengelola usaha dibidang masing-masing dan relasi (S2), serta didukung modal dana yang berasal dari Bpk. Abd. Nurawi untuk membeli beberapa ekor sapi sebagai modal usaha (S4).

Nampak Masjid Cheng Hoo dalam merencanakan berbagai usaha ekonomi terlahir dari strategi SO dan WO. Dengan memahami kebutuhan dan kondisi pasar, serta kebutuhan masyarakat secara umum. Lantas dikaitkan dengan potensi kekuatan yang ada pada internal serta peluang dari donatur. Proses merencanakan tersebut dilakukan dengan proses dialog antar pengurus yang beberapa diantara mereka memiliki background pengusaha. Dengan kemampuan dan pengalaman mereka yang jeli dalam membaca potensi usaha yang menguntungkan, sehingga tidak asal dalam melahirkan ide usaha ekonomi masjid.

Setelah menetapkan usaha ekonomi masjid, maka YHMCHI mulai membangun kerja sama dengan donatur dengan harapan mereka bisa memberi bantuan berupa pelatihan dan infrastruktur yang dapat digunakan untuk membangun usaha. ${ }^{74}$ Profil donatur Masjid Cheng Hoo sangat bervariasi, dari kalangan pengusaha hingga komunitas salah satunya alumni sekolah. Namun, yang cukup menarik adalah, donatur pengusaha yang membantu, ternyata ada yang berasal dari non Muslim. ${ }^{75}$ Mereka bersedia membantu karena ada kesamaan etnis Tionghoa, memandang pengurus $\mathrm{YHMCHI}$ bisa dipercaya dan relasi binis Bpk. Abd. Nurawi. ${ }^{76}$

Adapun beberapa strategi yang dilakukan dalam membangun kerja sama tersebut yakni: (1) Silaturahmi pengurus yang diadakan 3 bulan sekali. Dalam momen tersebut, pengurus menginformasikan perkembangan masjid dan gambaran usaha kemandirian yang akan dilaksanakan. Agar donatur berminat, pihak pengurus juga memberikan tawaran bantuan untuk memasarkan produk pengusaha, seperti memperkenankan mereka memasang spanduk di area masjid Cheng Hoo Surabaya; ${ }^{77}$ (2) Menggunakan media lain sebagai sarana komunikasi yakni memberikan majalah dua bulanan yang berisi kegiatan Masjid Cheng hoo yang sudah berjalan, perkembangan masjid, rencana pengembangan kedepan, ${ }^{78}$ artikel tausiyah keislaman dan beberapa iklan dari donatur; (3) Mengundang para donatur disetiap event yang diadakan masjid Cheng Hoo, misalkan saat event Milad ke-15 Masjid Cheng Hoo; ${ }^{79}$ (4) Senantiasa menjaga kepercayaan donatur dengan berusaha disiplin disetiap pertemuan, mengingat karakter umum donatur yang sangat menghargai waktu. ${ }^{80}$

\footnotetext{
77. Ibid.

78. Ibid.

79. Ibid.

80. Wawancara dengan Abd. Nurawi, 10 Mei, 2017.
} 
Strategi tersebut berbasis pada strategi SO, yang diperoleh dari pertimbangan: (1) Potensi yang dimiliki oleh donatur yang memiliki sumber daya kemampuan, dana, infrastruktur dan relasi, mereka memiliki karakter yang memperhatikan prinsip kedisiplinan, kepercayaan, dan kemanfaatan sebuah program, sehingga membuat mereka cenderung selektif dalam menerima kerja sama (O4); (2) kekuatan dari personal Bpk. Abd. Nurawi (S3), yang memiliki kesamaan background dengan donatur yang mayoritas berasal dari etnis Tionghoa dan pengusaha sehingga terbangun kepercayaan terhadap program YHMCHI. Dan Pengurus Masjid Cheng Hoo beberapa diantaranya adalah seorang pengusaha (S2), sehingga paham betul bagaimana karakter mereka dan cara bersikap. Didukung pula dengan citra lembaga yang terbuka dan toleran (S6), sehingga pihak donatur memiliki anggapan Masjid Cheng Hoo bersikap netral dan bisa mengakomodir berbagai kepentingan. Yang berimplikasi sikap donatur juga menjadi terbuka dalam menjalin komunikasi dengan YHMCHI.

\section{3). Membangun Kerja Sama Dengan Pondok Pesantren.}

Langkah selanjutnya, pengurus $\mathrm{YHMCHI}$ membangun kerja sama dengan tiga pondok pesantren dalam usaha penggemukan sapi dan Cheng Hoomart. Namun diantara ketiga pondok pesantren tersebut, yang difokuskan dahulu adalah pondok pesantren Ngalah, Purwoasri. Tujuannya membangun kepercayaan kepada masyarakat tentang kualitas pengelolaan usaha peternakan yang digagas oleh Masjid Cheng Hoo, yang menggunakan teknologi laser puntur sebagai

81. Wawancara dengan Soebiantoro, 7 April, 2017.

82. Ibid. nilai jualnya. ${ }^{81}$ Adapun pertimbangan pihak Masjid Cheng Hoo memilih ketiga pondok pesantren tersebut yakni: memiliki jumlah SDM yang besar, moralitas ketakwaan dan kejujuran, memiliki kesamaan pemikiran Islam, dan beberapa memiliki usaha ekonomi sebelumnya. ${ }^{82}$

Usaha membangun kerja sama tersebut, diawali dengan silaturahmi antara Ketua YHMCHI dan Bpk. Soebiatoro selaku penggagas dengan pihak pengurus pondok pesantren. Mereka menyampaikan gambaran bentuk kerja sama, bagaimana proses bagi hasilnya dan rencana kedepan mengenai konsep Holding Company dan manfaat kerja sama bagi pihak pesantren. ${ }^{83}$

Strategi tersebut berbasis pada strategi SO yang dihasilkan dari proses pencocokan (1) Potensi sumber daya manusia yang dimiliki oleh pondok pesantren (pengurus, santri dan keluarganya) berpeluang mendukung kesuksesan usaha peternakan sapi. Disamping adanya kesamaan pandangan ingin bisa hidup mandiri dan pemikiran Islam, membuat peluang kerja sama tersebut semakin besar(05); (2) Antara ketiga pondok pesantren memiliki kesamaan, kyainya lulusan Al-Ahzar, Cairo (O5), sehingga berpeluang mudah untuk diajak kerja sama karena sudah mengenal satu dengan lainnya. Sementara dari aspek internal, yang menjadi kekuatan adalah Bpk. Nurawi dan Bpk. Subiantoro (S2) selaku penggagas usaha peternakan sapi sehingga memahami bagaimana gambaran program tersebut. Disamping pengalaman mereka sebagai pengusaha yang identik dengan membangun relasi dengan pengusaha lain, memudahkan dalam proses penawaran

83. Wawancara dengan Abd. Nurawi, 10 Mei, 2017. 
kerja sama. Didukung pula dengan citra lembaga yang terbuka dan toleran (S6), sehingga pihak pesantren memiliki anggapan Masjid Cheng Hoo bersikap netral. Implikasinya mereka cenderung juga terbuka dalam menjalin komunikasi dengan YHMCHI.

\section{4). Membangun Kesiapan SDM Yang Menjalankan Usaha}

SDM merupakan salah satu faktor penentu kesuksesan sebuah strategi, karena itu pengurus Masjid Cheng Hoo memperhatikan betul kualitas SDM yang dimiliki, baik secara kemampuan dan moralitas. Yang dimaksud SDM disini bukan hanya pengurus Masjid Cheng Hoo, melainkan pihak eksternal yang ditunjuk untuk menjalankan usaha.

Dalam membentuk kemampuan, Pihak pengurus Masjid Cheng Hoo memberikan pelatihan dengan melibatkan para ahli dibidangnya. Seperti melakukan kerja sama dengan Prof. Tatang dan Prof. Heri, Dokter Hewan UNAIR untuk memberikan pelatihan sekaligus turut memantau pengelolaan peternakan sapi di tiap pondok pesantren. ${ }^{84}$

Tak jarang dalam pelatihan tersebut, pihak pengurus Masjid Cheng Hoo memberikan pengetahuan bagaimana membangun bisnis yang Islami. Seperti yang pernah mereka lakukan saat memberikan pelatihan ketrampilan membuat kue untuk beberapa UKM Se-Jawa Timur yang melibatkan PT. Bogasari. Harapannya, ketika mereka membangun usaha tidak hanya mencari untung, melainkan bisa memberikan kemanfaatan bagi pihak lain, sebagaimana prinsip ekonomi madani yang menjadi pondasi usaha kemandirian Masjid Cheng Hoo.

\footnotetext{
84. Wawancara dengan Hasan Basri, 4 April, 2017.
}

Untuk mengkoordinasi semua usaha kemandirian yang telah dirancang tersebut, supaya berjalan sinergis dan optimal, pihak pengurus membentuk Tim Ekonomi. Menurut Ketua $\mathrm{YHMCHI}$, tim inilah yang akan bertugas mencari peluang-peluang kerja sama dengan pondok pesantren dan donatur..$^{85}$

Strategi tersebut berbasis dari strategi SO dan ST, yang dihasilkan dari proses pencocokan: (1) Peluang dukungan dari para donatur yang mayoritas adalah pengusaha baik dalam bentuk tenaga ahli, bahan, infrastruktur dan teknologi (04), yang mampu direspon dengan kekuatan pengurus Masjid Cheng Hoo yang juga merangkap sebagai pengusaha, melalui kemampuan, pengalaman dan relasi yang dimiliki berpeluang untuk menawarkan kerja sama dengan donatur, membantu ide pengembangan usaha serta cara pengelolaannya (S3). Namun, juga terdapat hambatan (T1) pandangan yang dimiliki pondok pesantren, menyangkut pandangan zuhud/pasrah pada keadaan, yang dimaknai hidup itu dijalani dengan santai, dan menyerahkan segala keadaan, membuat mereka sulit diajak untuk maju dan berkembang. Serta kondisi UKM yang memiliki pandangan berbeda dengan konsep ekonomi madani yang dimiliki Masjid Cheng Hoo (T3). Menyikapi hal tersebut, Masjid Cheng Hoo memiliki citra sebagai masjid terbuka untuk melakukan dialog keislaman, sebagaimana visi masjid yakni sebagai wadah yang menjembatani perbedaan pemikiran Keislaman melalui dialog (S6).

85. Wawancara dengan Abd. Nurawi, 10 Mei, 2017. 


\section{5). Penggunaan Tekonologi Untuk Memantau Perkembangan Usaha}

Demi kecepatan dan transparansi keuangan, pihak pengurus Masjid Cheng Hoo menggunakan sebuah software untuk memantau perkembangan usaha ditiap pondok pesantren. Menurut Ketua YHMCHI, semua bisnis baik peternakan sapi, beras dan Cheng Hoomart di pondok pesantren yang diajak kerja sama, telah menggunakan software tersebut. ${ }^{86}$ Dengan adanyasoftware tersebut, memiliki beberapa manfaat: (1) Diharapkan pengelolaan usaha di tiap pondok pesantren seperti perusahaan yang profesional. Yang mana baik pihak Masjid Cheng Hoo dan pengurus pondok, dapat memantau progres usaha dan pengelolaan keuangannya; (2) Adanya laporan tersebut mampu meningkatkan kepercayaan donatur karena modal yang diberikan ternyata mampu dikelola dengan optimal dan amanah; (3) Memudahkan pengurus Masjid Cheng Hoo dalam memantau, tanpa harus sering berkunjung ke tiap pesantren.

Strategi tersebut berbasis strategi WO dan SO yang diperoleh dari proses pencocokan hambatan kondisi internal pengurus dengan kesibukannya tidak memungkinkan mengontrol perkembangan usaha tiap pesantren (W1), namun dapat diatasi dengan dukungan modal dana dan teknologi dari para donatur (O4) dan pengurus YHMCHI (yang merangkap pengusaha) (S2) sehingga realistis untuk dijalankan.

Berikut ini merupakan tabel matriks analisis kekuatan-kelemahan-peluang-ancaman strategi Masjid Cheng Hoo dalam membangun kemandirian masjid:

Tabel 1 - Matriks Analisis SWOT Strategi Membangun Kemandirian Masjid Cheng Hoo

\begin{tabular}{|c|c|c|}
\hline $\begin{array}{c}\text { Matriks } \\
\text { SWOT }\end{array}$ & $\begin{array}{l}\text { Kekuatan (S) } \\
\text { 1. Pengurus yang memiliki kemampuan } \\
\text { dasar (pemecahan masalah yang } \\
\text { baik), waktu dan moral untuk } \\
\text { profesional (S1). } \\
\text { 2. Pengurus yang juga menjadi } \\
\text { pengusaha, memiliki kemampuan } \\
\text { mengelola usaha dibidang masing- } \\
\text { masing dan relasi (S2). } \\
\text { 3. Figur dan relasi pengusaha Ketua } \\
\text { YHMCHI (S3). } \\
\text { 4. Dana milik Ketua YHMCHI sebagai } \\
\text { modal usaha awal (S4). } \\
\text { 5. Aset masjid yang bisa dikembangkan } \\
\text { (S5). } \\
\text { 6. Citra yang terbuka dan toleran } \\
\text { terhadap perbedaan (S6). } \\
\text { 7. Pola kontrol mingguan berupa forum } \\
\text { silaturahmi (S7). }\end{array}$ & $\begin{array}{l}\text { Kelemahan (W) } \\
\text { 1. Tingkat kesibukan } \\
\text { pengurus yang menjadi } \\
\text { pengusaha cukup tinggi } \\
\text { sehingga sulit ditemui } \\
\text { (W1). }\end{array}$ \\
\hline $\begin{array}{l}\text { Peluang }(0) \\
\text { 1. Tingginya kebutuhan wisatawan } \\
\text { lokal }(\mathrm{O} 1) \text {, } \\
\text { 2. Keluarga }(\mathrm{O} 2) \text {, } \\
\text { 3. Trend remaja terhadap olah raga } \\
\text { basket (O3). } \\
\text { 4. Donatur yang memiliki sumber } \\
\text { daya kemampuan, dana, }\end{array}$ & $\begin{array}{l}\text { - Membangun Komitmen Pengurus } \\
\text { Masjid (S2,S3, S7) } \\
\text { - Mendirikan Usaha demi } \\
\text { terwujudnya Kemandirian Ekonomi } \\
\text { Masjid. } \\
\text { a) koperasi \& kafe }(\mathrm{O} 1-3, \mathrm{~S} 5) \\
\text { b) Cheng Hoo mart }(\mathrm{O} 5,4,8, \mathrm{~S} 1, \mathrm{~S} 2) \\
\text { c) Cheng Hoo Bakery, }(06, \mathrm{O} 4, \mathrm{~S} 2)\end{array}$ & $\begin{array}{l}\text { Membangun Komitmen } \\
\text { Pengurus Masjid dengan } \\
\text { memanfaatkan pola kontrol } \\
\text { minggu melalui forum jumat } \\
(\mathrm{W} 1, \mathrm{S7}, \mathrm{S3}) \text {. }\end{array}$ \\
\hline
\end{tabular}

86. Ibid. 
infrastrukur, teknologi dan relasi (04).

5. Pesantren yang memiliki sumber daya manusia, memiliki kesamaan relasi dan usaha mandiri yang bisa dioptimalkan (05).

6. 300 UKM dan jemaah masjid (06).

7. Terbatasnya pasokan daging sapi di Indonesia (07)

8. Perkembangan usaha ritel menjadi inspirasi bagi $\mathrm{YHMCHI}$ untuk mendirikan usaha Cheng Hoo mart (08).

Ancaman ( $\mathrm{T}$ )

1. Pandangan budaya santai dan menyerahkan semua kepada Allah dimiliki pesantren (T1)

2. Kondisi UKM yang memiliki pandangan berbeda dengan konsep ekonomi madani (T2). d) Penggemukan sapi (O4-07, S2, S4).

- Membangun Kerja Sama Dengan Donatur (O4, S2, S3, S6).

- Membangun kerja sama dengan pondok pesantren $(05, \mathrm{~S} 2, \mathrm{~S} 6)$.

- Membangun Kesiapan SDM (pelatihan) yang menjalankan usaha $(04,53)$.
- Mengadakan dialog pemikiran perbedaan pemikiran dalam membangun usaha $(\mathrm{T} 3, \mathrm{~S} 6)$.

\section{Kesimpulan}

Misi kemandirian masjid Cheng Hoo merupakan bagian dalam mewujudkan visi masjid untuk memberikan kemanfaatan bagi masyarakat. Dilain pihak juga mendukung sumber daya dana yang dibutuhkan untuk menjalankan program masjid.

YHMCHI memahami kondisi internal masjidyang menjadi kekuatan meliputi: citra organisasi yang terbuka dan toleran,pengurus yang memiliki pengalaman, relasi, kemampuan mengeloa bisnis sebagai pengusaha, dan dukungan dana, aset masjid yang bisa dikembangkan. Dan kelemahan berupa tingkat kesibukan pengurus yang menjadi pengusaha cukup tinggi. Serta memahami kondisi eksternal, meliputi aspek peluang: kebutuhan dan keinginan pasar, sumber daya donatur disisi dana, kemampuan sebagai pengusaha dan teknologi, sumber daya pesantren berupa manusia dan usaha mandiri yang bisa dioptimalkan, UKM dan jemaah masjid, masalah terbatasnya pasokan daging sapi. Dan ancaman: pandangan hidup zuhud pesantren, karakter donatur yang selektif, perkembangan usaha ritel, UKM yang memiliki pandangan berbeda dengan konsep ekonomi madani.

Adapun beberapa strategi yang dilakukan Masjid Cheng Hoo, mayoritas terlahir dari strategi SO yakni: (1) merencanakan berbagai usaha ekonomi, meliputi: koperasidan kafe, Cheng Hoo Mart, Cheng Hoo Bakery, dan peternakan sapi; (2) Membangun kerja sama dengan donatur 4) Membangun kerja sama; (3) Membangun kesiapan SDM berupa pelatihan, dan (6) Penggunaan teknologi untuk pengawasaan. Adapula strategi yang lahir dari WT yakni membangun kesiapan SDM dalam aspek pola berfikir dalam menjalankan usaha. Serta strategi yang lahir dari hanya pembacaan kondisi SW yakni membangun komitmen pengurus terhadap gagasan mewujudkan kemandirian masjid.

Bagi lembaga dakwah terutama masjid yang hendak mewujudkan kemandirian masjid, ada beberapa hal yang bisa diambil hikmah dari studi ini yakni: (1) konsep ekonomi madani dalam membangun usaha masjid 
cukup menarik apabila diadaptasikan ke masjid yang ada di Indonesia. Sehingga bukan hanya menjadikan masjid berdaya namun, bisa memberikan kontribusi nyata terhadap masalah umat seperti kemiskinan salah satunya; (2) cara memandang donatur bukan sekedar orang yang memberi, namun sebagai investor. Sehingga dalam menjalankan usaha memunculkan tanggung jawab bukan sekedar menjalankan melainkan mengembangkan usaha, atas dana yang telah diamanahkan oleh donatur; (3) gagasan kemandirian masjid, tidak akan bisa terealisasi tanpa adanya kesepakatan pandangan berbagai pihak, dan pemimpin merupakan ujung tombak yang diharapkan mampu membangun komitmen tersebut; (4) perlunya mengelola usaha masjid secara profesional sebagaimana perusahaan salah satunya ada sistem kontrol sejauh mana usaha berkembang yang dijalankan secara terus menerus.

\section{Bibliografi}

Affandy, Shofyan. Dakwah Strategik. Surabaya : Avvatera,2017.

Aisyah, Siti. "Membangun Kekuatan Ekonomi Masjid (Studi Kasus Masjid Muhammadiyah Padang)". Jurnal Syariah, Vol. II, No. II (2013): 51-62. doi: https://doi.org/10.32520/.v1i2.12

Arif,Muhammad. Model Pemberdayaan Ekonomi Terhadap Kemandirian Masjid Haji Maraset, At-Tawassuth, Vol.III, No.2 (2018):423-440. doi: http://dx.doi.org/10.30821/ajei.v1i1.2744

Dalmeri, "Revitalisasi Fungsi Masjid Sebagai Pusat Ekonomi Dan Dakwah Multikultural", Walisongo, Vol. 22, No. 2 (2014): 321-350. doi: 10.21580/ws.22.2.269

David, Fred R. Manajemen Strategis konsep. Jakarta : Salemba Empat, 2012.

Hasan, Burnadi. Indahnya Perbedaan, Cetakan Kedua. Surabaya: (Persatuan Islam Tionghoa Indonesia \& Yayasan Haji Muhammad Cheng Hoo), 2016. doi: http://dx.doi.org/10.31602/iqt.v2i2.377

Hasan, Burnadi. Indahnya Perbedaan, Cetakan Kedua. (Persatuan Islam Tionghoa Indonesia \& Yayasan Haji Muhammad Cheng Hoo : Surabaya. Oktober 2016.

Hentika, Niko Pahlevi, "Menuju Restorasi Fungsi Masjid: Analisis Terhadap Handicap Internal. doi: https://doi.org/10.14421/jmd.2016.\%25x

Huda, Miftahul, "Kemandirian Berbasis Waqaf di Masjid Besar Imam Ulomo Sampung Ponorogo", Al-Ihkam, Vol. 12 No 2 (Desember): 362-384. doi: 10.19105/alihkam.v12i12.1510

Marjayanti, Dian. "Strategi Pengembangan Masjid Cheng Hoo Berbasis Kemandirian." Tesis- IAIN Surabaya, 2017.

Muna, Muhammad Niltal dan Meri Indri Hapsari. "Implementasi Manajemen Strategik Syariah Di BMT Amanah Ummah", JESTT. Vol. 2, No. 12 (Desember 2015): 1052-1068. doi: http://dx.doi.org/10.20473/vol2iss201512pp1052-1068.

Muslim, Aziz. "Manajemen Pengelolaan Masjid" Aplikasia, Jurnal Aplikasi Ilmu-Ilmu Agama, Vol.V, No. 2 (Desember 2004): 105-114. doi: http://digilib.uin- 
suka.ac.id/8309/1/AZIZ\%20MUSLIM\%20MANAJEMEN\%20PENGELOLAAN\%20MASJID.pd f.

Nuraida, "Konsep kemandirian dalam pengembangan Masjid", Yonetim, Vol 1 No 1 (2018):1 33. doi: http://jurnal.radenfatah.ac.id/index.php/yonetim/article/view/2957

Rifai, Ahmad. Revitalisasi Fungsi Masjid Dalam Kehidupan Masyarakat Modern, Universum, Vol.10, No. 2 (2016): 155-163. doi: https://doi.org/10.30762/universum.v10i2.256

Sugiyono. Metode Penelitian Kuantitatif, Kualitatif dan R\&D. Bandung: Alfabet, 2012.

Suryorini, Ariana dan Bambang Sumardjoko. "Pemberdayaan Masjid sebagai Fungsi Sosial dan Ekonomi bagi Jamaah Pemegang Saham Unit Usaha Bersama", Dimas: Jurnal Pemikiran Agama untuk Pemberdayaan, Vol.19 No. 2 (2019): 163-178. doi: https://core.ac.uk/download/pdf/287171587.pdf

Tamam. "Ciptakan Kemandirian, YHMCHI Gandeng Peternak di Purwosari". ChengHoo.co. 13 Januari, 2021.http://chenghoo.co/2018/07/25/ciptakan-kemandirian-yhmchi-gandengpeternak-di-purwosari/. (diakses 13 Januari, 2021).

Tanaja, Tasha Victoria dan Lintu Tulistyantoro. "Kajian Ikonografi Ornamen pada Interior Masjid Cheng Hoo Surabaya", JURNAL INTRA, Vol. 5, No. 2 (2017): 174-181. doi: http://publication.petra.ac.id/index.php/desain-interior/article/view/5763

Usman, Nurodin. "Varian Mauquf 'Alaih 'Am sebagai Alternatif dalamPengembangan Wakaf Produktif", al-ahkam, jurnal ilmu Syariah daN Hukum, Vol. 2, No. 1 (2017): 47.

Wardi, Moch. Cholid. "Pencarian Dana Masjid Di Jalan Raya Dalam Perspektif Hukum Islam", AlIhkam: Jurnal Hukum dan Pranata Sosial, Vol. 7 N o. 2, (D e s e m b e $r 2$ 01 2):331-354. doi:

https://www.researchgate.net/profile/Moch Wardi/publication/325556531 PENCARIA N DANA MASJID DI JALAN RAYA DALAM PERSPEKTIF HUKUM ISLAM/links/5b15e88 5aca272d43b7e8a6b/PENCARIAN-DANA-MASJID-DI-JALAN-RAYA-DALAM-PERSPEKTIFHUKUM-ISLAM.pdf

Zuhri, Achmad Muhibin dan Winarto Eko Wahyudi. "Teologi Sosial Muslim Tionghoa : Keimanan, Identitas Kultural Dan Problem Eksistensial", Empirisma, Jurnal pemikiran dan kebudayaan Islam, Vol. 29, No. 2, (Juli 2020):103-111. doi : https://doi.org/10.30762/empirisma.v29 
